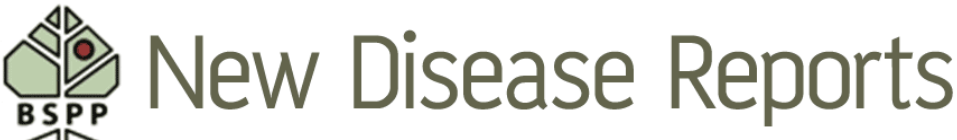

\section{First record of Erysiphe salmonii causing powdery mildew on Fraxinus ornus in Switzerland}

\author{
L. Beenken ${ }^{1} *$ and T. Brodtbeck ${ }^{2}$ \\ ${ }^{1}$ Swiss Federal Research Institute WSL, CH-8903 Birmensdorf, Switzerland ; ${ }^{2}$ Elsternweg 5, CH-4125 Riehen, Switzerland \\ *E-mail: ludwig.beenken@wsl.ch
}

Received: 25 Nov 2020. Published: 15 Dec 2020. Keywords: Erysiphales, manna ash, obligate parasite, Uncinula

In Switzerland, the manna ash (Fraxinus ornus) is native to the canton Ticino (https://www.infoflora.ch). In September and October 2020 a powdery mildew species of the genus Erysiphe sect. Uncinula was discovered in four native stands of $F$. ornus in southern Ticino. These were on the southern slope of Mt. Brè between Lugano and Gandria (ZT Myc 64438), at Mt. San Salvatore close to its summit (ZT Myc 64439), at Mt San Giorgio close to Meride (ZT Myc 64440) and north of Morbio Inferiore (ZT Myc 64441) $(\mathrm{ZT}$ Myc $=$ vouchers in fungal herbarium of ETH Zurich). In these areas, the species was found on several seedlings and mature trees and therefore the disease is considered widespread where it is found. The current distribution in Switzerland will be continuously updated on https://swissfungi.wsl.ch/en/distribution-data/distribution-atlas.html.

The morphological characteristics of the chasmothecia found on the leaves but rarely on the fruits of $F$. ornus fit Erysiphe salmonii as described and illustrated in Braun \& Cook (2012) and Heluta et al. (2017). Mycelium was amphigenous but mainly epiphyllous. Chasmothecia were scattered and measured 80-120 $\mu \mathrm{m}$ in diameter, had 10-20 appendices, 70-130 $\mu \mathrm{m}$ long and 5-7 $\mu \mathrm{m}$ wide (to $9 \mu \mathrm{m}$ towards the tip), which were pigmented at the base and with one septum. Apices were spirally curved. Chasmothecia had 2-5 ovoid asci measuring 50-60 $\times 30-50 \mu \mathrm{m}$ with 6-8 ellipsoid ascospores per ascus, each measuring $15-20 \times 7-10 \mu \mathrm{m}$. Conidiophores and conidia were not observed.

To confirm the morphological identification, two representative samples (ZT Myc 64438 \& 64441) were investigated using molecular methods. The ITS region of nrDNA was sequenced using the Erysiphales-specific primer pair PMITS1/ PMITS2 (Cunnington et al., 2003) following Beenken (2017). Resulting sequences were deposited in GenBank (Accession Nos. MW265934 and MW265935). An NCBI BLAST search confirmed the identification of the Swiss powdery mildew samples as E. salmonii. Both sequences showed $100 \%$ identity to sequences of E. salmonii found on Fraxinus mandshurica in Japan (LC028981), on F. rhynchophylla in South Korea (MH880101-02) and on F. chinensis in China (MT919716). Erysiphe salmonii originated from East Asia (Braun \& Cook 2012). Heluta et al. (2017) detected E. salmonii on Fraxinus excelsior and F. pennsylvanica in Ukraine and this was the only record for Europe up to now. Interestingly, the ITS sequences (LC259500 and LC259502) of their samples differ in one base pair from those from Switzerland. In Switzerland, the species was only found on $F$. ornus but not on $F$. excelsior trees grow in the sampled areas. However, further work is necessary to determine the significance of this finding.

\section{References}

1. Beenken L, 2017. First records of the powdery mildews Erysiphe platani and E. alphitoides on Ailanthus altissima reveal host jumps independent of host phylogeny. Mycological Progress 16, 135-143. http://dx.doi.org/10.1007/s11557-016-1260-2

2. Braun U, Cook RTA, 2012. Taxonomic manual of the Erysiphales (powdery mildews), CBS Biodiversity Series . Utrecht, The Netherlands: Centraalbureau voor Schimmelcultures.

3. Cunnington JH, Takamatsu S, Lawrie AC, Pascoe IG, 2003. Molecular identification of anamorphic powdery mildews (Erysiphales). Australasian Plant Pathology 32, 421-428. http://dx.doi.org/10.1071/AP03045

4. Heluta VP, Takamatsu S, Siahaan SAS, 2017. Erysiphe salmonii (Erysiphales, Ascomycota), another East Asian powdery mildew fungus introduced to Ukraine. Ukrainian Botanical Journal 74, 212-219. http://dx.doi.org/10.15407/ukrbotj74.03.212

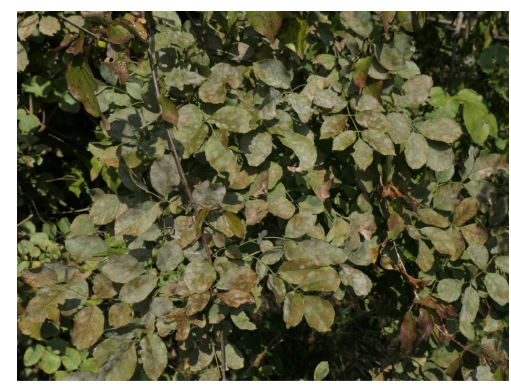

Figure 1

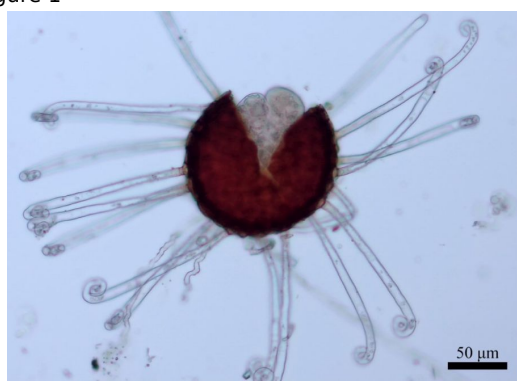

Figure 4

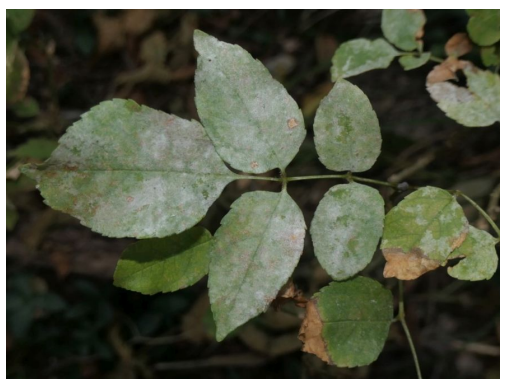

Figure 2

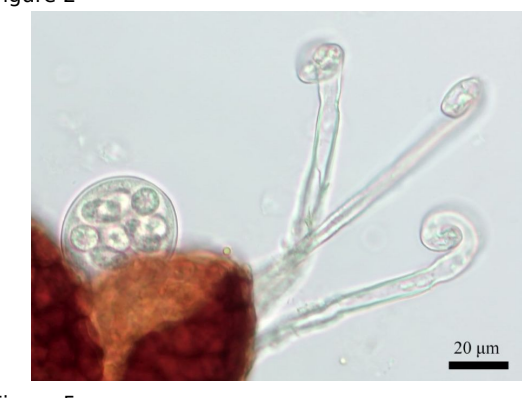

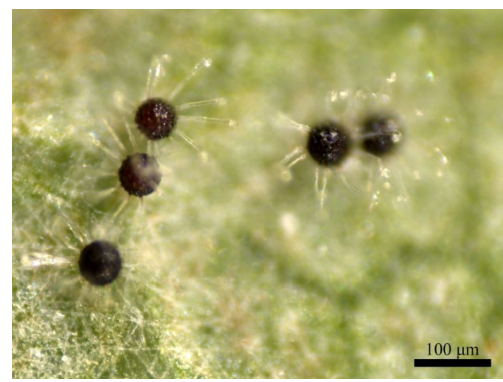

Figure 3

To cite this report: Beenken L, Brodtbeck T, 2020. First record of Erysiphe salmonii causing powdery mildew on Fraxinus ornus in Switzerland. New Disease Reports 42, 22. http://dx.doi.org/10.5197/j.2044-0588.2020.042.022

(c) 2020 The Authors

This report was published on-line at www.ndrs.org.uk where high quality versions of the figures can be found. 